\title{
Assessment of Knowledge Levels of Elementary and High School Teachers on Childhood Asthma
}

\author{
İlköğretim ve Lise Öğretmenlerinin Çocukluk Çağı Astımı ile illgili Bilgi Düzeylerinin \\ Değerlendirilmesi \\ (D) Öner Özdemir¹, (D) Murat Sürücü² \\ 1Sakarya University Faculty of Medicine, Department of Pediatric Allergy and Immunology, Sakarya, Turkey \\ 2University of Health Sciences, Gazi Yașargil Training and Research Hospital, Clinic of Pediatric Cardiology, Diyarbakır, Turkey
}

\begin{abstract}
Introduction: Asthma is a major cause of absenteeism in schoolage children. Studies have shown that teachers' knowledge of asthma reduces school attendance rates. Collaboration between patients, physicians, family and teachers is an important factor in the success of treatment and decrease in the frequency of attacks in asthma patients. In order for teachers to take a more active role in this cooperation, their knowledge levels should be increased by providing trainings on childhood asthma. The aim of this study was to evaluate the knowledge levels of elementary (primary and secondary) and high school teachers working in İstanbul regarding childhood asthma.
\end{abstract}

Methods: This questionnaire was conducted between June and December 2012 with the participation of 825 teachers working in 22 randomly selected schools. The questionnaire was given to the teachers participating in the study, which questioned the general information, symptoms, triggering factors of asthma crisis, emergency intervention and treatment information about childhood asthma.

Results: In our study, the level of general knowledge about childhood asthma was found to be the highest and the level of knowledge about asthma triggering factors was the lowest. Regarding gender, the mean scores of the female teachers about asthma were significantly higher than male teachers. The total asthma awareness scores of the teachers working in public schools were found to be significantly lower than the teachers working in private schools $(p=0.001)$. Having asthma experience was found to cause a significant increase in childhood asthma knowledge scores of teachers $(p=0.001)$. When the comparison was made according to the expertise in teaching, experienced teachers had more knowledge about asthma triggering factors, whereas the teachers with less professional experience were more knowledgeable about the emergency intervention in asthma attack $(p=0.016)$.

Conclusion: Our study will contribute to the national asthma control program. We believe that informing teachers about asthma is important in asthma control and will contribute to the guidelines for training programs.

Keywords: Asthma, childhood, teacher, school, knowledge level

\section{ÖZ}

Amaç: Astım okul çağı çocuklarında devamsızlığın başta gelen nedenlerindendir. Yapılan çalıșmalar öğretmenlerin astım hakkında bilgi sahibi olmasının okula devamsızık oranlarını azalttığını göstermektedir. Astım hastalarında tedavi başarısı ve atak sıklığının azalması için hasta, doktor, aile ve öğretmen arasındaki iş birliği önemli bir unsurdur. $\mathrm{Bu}$ iş birliğinde öğretmenlerin daha etkin rol alabilmeleri için çocukluk çağı astımı hakkında eğitimler verilerek bilgi düzeyleri artırılmalıdır. Çalıșmanın amacı; İstanbul ilinde görev yapan ilköğretim ve lise öğretmenlerinin çocukluk çağı astımı ile ilgili bilgi düzeylerinin değerlendirilmesidir.

Yöntemler: Bu anket çalışması randomize olarak seçilen toplam 22 okulda görev yapan 825 öğretmenin katılımı ile Haziran-Aralık 2012 tarihleri arasında yapıldı. Çalıșmaya katılan öğretmenlere çocukluk çağı astımı hakkında genel bilgileri, belirtileri, astım krizini tetikleyen faktörleri, ilk müdahale ve tedaviyle ilgili bilgileri sorgulayan bir anket formu dağıtıldı.

Bulgular: Çalışmamızda; çocukluk çağı astımı genel bilgisine ilișkin bilgi düzeyi puanı en yüksek, astım tetikleyici faktörlere ilișkin bilgi düzeyi puanı en düșük bulundu. Cinsiyete göre değerlendirmede kadın öğretmenlerin astımla ilgili verdikleri cevapların puanlarının ortalaması erkek öğretmenlerden anlamlı șekilde yüksek bulundu. Okul türlerine göre devlet okulunda görev yapan öğretmenlerin astım bilinci total puanları, özel okulda görev yapan öğretmenlere göre anlamlı şekilde düşük bulundu. Astım ile ilgili yaşanmış deneyimi olmasının öğretmenlerin çocukluk çağı astımı bilgi puanlarında anlamlı oranda yükselmeye neden olduğu bulundu. Öğretmenlik süresine yani mesleki deneyime göre karşılaştırma yapıldığında astım tetikleyici faktörler konusunda deneyimli öğretmenler daha fazla bilgiye sahipken, astım atağında ilk müdahaleye ilișkin ise mesleki deneyimi az olan öğretmenlerin daha bilgili olduğu görüldü.

Sonuç: Bu çalıșma öğretmenler için gerçekleștirilecek eğitim programları ve seminerler için ulusal bir rehber hazırlanmasına yardımcı olması açısından önemlidir.

Anahtar Kelimeler: Astım, çocukluk çağı, öğretmen, okul, bilgi düzeyi 


\section{Introduction}

Asthma is one of the most common chronic diseases in childhood and is one of the main reasons for absenteeism and low participation in school activities such as gymnastics (1-11). One study showed that $7 \%$ of the students could not go to school on average seven days a year due to wheezing, and another study showed that $67 \%$ of the students did not attend school at least once a year due to wheezing or asthma $(8,9)$.

Children spend an important part of their day at school separately from their families, which causes anxiety in families of children with chronic diseases such as asthma. Studies have shown that teachers' knowledge about asthma reduces family anxiety and child absenteeism rates. It is important for teachers to recognize the symptoms of asthma at the beginning of the attack and to know how to use the drugs to prevent the development of severe attacks. If the factors that trigger the development of asthma attacks are known by the teacher, inappropriate environmental conditions in the school will be corrected, thus preventing attack development. Since there are no nurses or health personnel in most of the primary schools in our country, it is very important that teachers are made aware of this issue. In some developed countries, projects such as "asthma friendly school" have been developed for the care of children with asthma at school (12-14).

In this study, a questionnaire consisting of general information, symptoms, triggering factors, first intervention and treatment during the attack in childhood asthma was distributed to the teachers and their level of knowledge was tried to be determined, and it was aimed to provide information that could guide future trainings and national programs to be developed.

\section{Methods}

This study was conducted between June and December 2012 with the aim of measuring the level of knowledge of primary and high school teachers about childhood asthma in various public and private schools in İstanbul under the responsibility of a Training and Research Hospital Pediatric Clinic.

In this study, 20 elementary schools (primary and secondary schools) and 2 high schools were visited and questionnaires were distributed to approximately 1000 teachers. Nine hundred teachers agreed to participate in the study and completed the questionnaire appropriately (rate of answering the questionnaire: 90\%). Of the 900 questionnaires, 825 were included in the study and the remaining 75 were excluded from the study due to inadequate answering.

In the questionnaire used in this study, there are questions regarding general demographic information (age, gender, expertise in teaching, education level, school type etc.) about the teachers. The questionnaire consists of three questions about the asthma experience asking whether there is a child with asthma in the family/school, one question about smoking and one illustrated question about the use of spray/inhalertype medications used by the asthmatic child. In the next part of the questionnaire, there are a total of 41 questions including nine questions on general information about asthma, six questions questioning the relationship of some symptoms with asthma, seven questions about factors triggering asthma crisis, four questions about emergency intervention in asthma crisis, nine questions about asthma treatment and one question related to the training seminar (Figure 1).
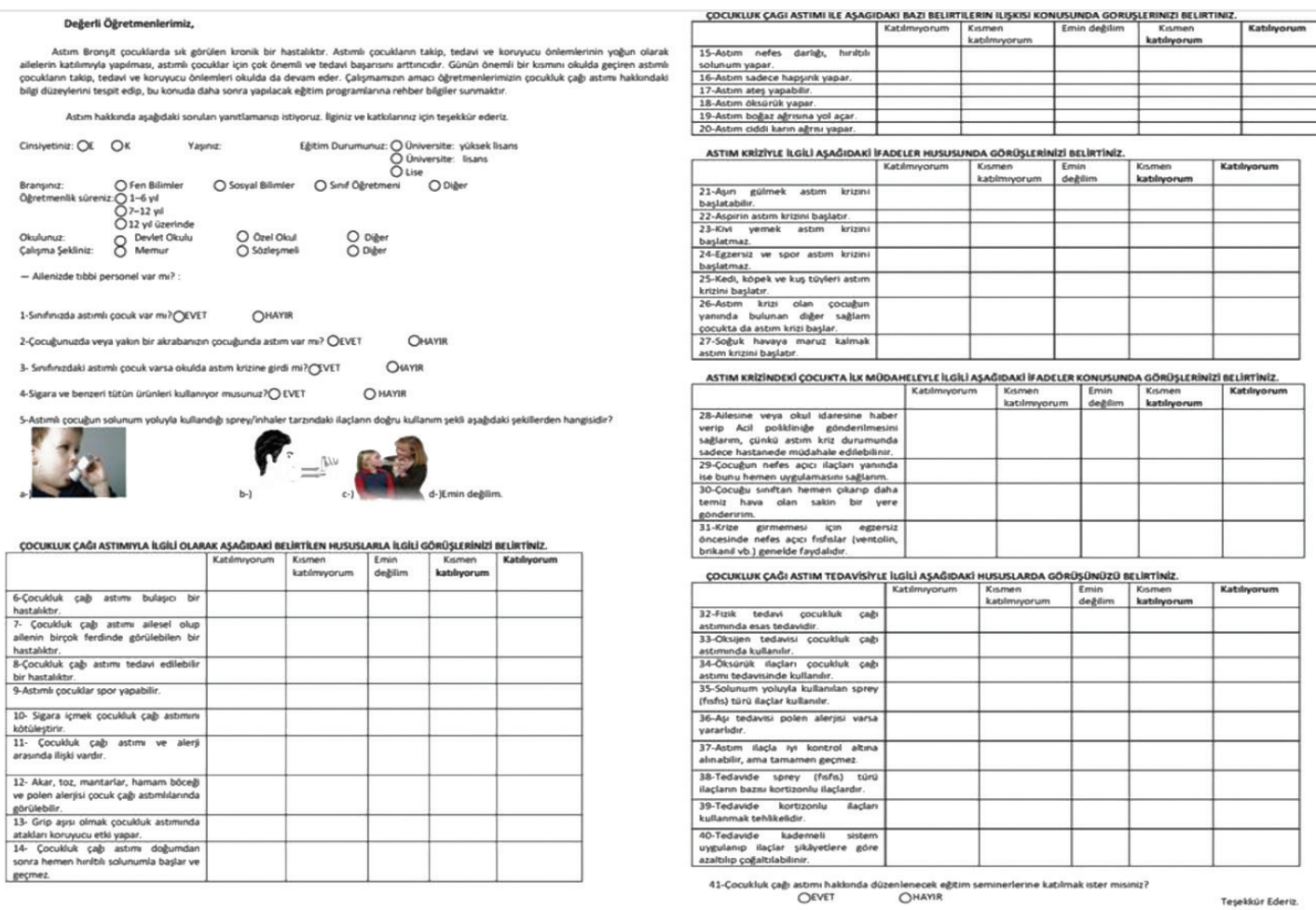

Figure 1. The questionnaire 
In the evaluation of the questionnaire, a 5-point Likert scale, including "strongly agree", "agree", "neither agree nor disagree", "disagree" and "strongly disagree" choices, was used. The correct answer was given "5 points" and the other answers were scored as " 4 , 3, 2, 1" points according to the closeness to the correct answer. After calculating the scores of the parts, 100-point conversion was applied to the total points obtained, thus the highest score being 100 and the lowest score being 0 .

Questionnaire results were evaluated separately for five main parts and under asthma awareness total score title for the total score of 35 questions. In addition, the answers were evaluated separately according to gender, education level (university/bachelor's degree and master's degree), teacher's field of study, smoking status, expertise in teaching (professional experience), type of school (public, private) and asthma experience (the presence of asthmatic individuals in the family or school).

Informed verbal and written informed consent was obtained from the teachers. Ethics committee approval was obtained for the study (Istanbul University Training and Research Hospital Ethics Committee (decision no: 16/J, date: 25/10/2011).

\section{Statistical Analysis}

Statistical analysis was performed using Number Cruncher Statistical System 2007\&PASS (Power Analysis and Sample Size) 2008 Statistical Software (Utah, USA). In the evaluation of the study data, descriptive statistical methods (mean, standard deviation, median, frequency, percentage) were used. One-way ANOVA with post-hoc Tukey HSD was used for the comparison of quantitative data with normal distribution and determining the source of the difference. Student's t-test was used in pairwise comparisons. Significance was evaluated at $p<0.05$.

\section{Results}

The study was conducted with 825 teachers (500 females, 325 males) between June 2012 and December 2012. The mean age of the teachers

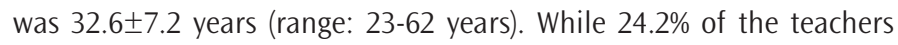
were smokers, $75.5 \%$ did not smoke. Fourteen point five percent of the teachers $(n=120)$ had master's degree and $84.5 \%(n=705)$ had bachelor's degree. Fourteen point five percent of the teachers were in the field of science, $12.5 \%$ were in the social sciences, $33 \%$ were in other fields and $40 \%$ were classroom teachers. Forty-three point seven percent of the teachers were working for $1-6$ years, $31.1 \%$ for $7-12$ years and $25.1 \%$ for more than 12 years. Eighty-two point eight percent of the teachers $(n=684)$ were working in public schools and $17.2 \%(n=141)$ were in private schools. While $38.7 \%$ of the teachers $(n=320)$ had children with asthma in their classes, $61.3 \%(n=505)$ did not have any children with asthma in their classes. While $37.5 \%$ of the teachers had asthma in their kids or close relative's kids, $62.5 \%$ did not have any asthma in their kids or close relative's kids.

While $5.1 \%$ of the teachers had children with asthma attacks in their classes, $94.9 \%$ did not have children with asthma attacks in their classes. Regarding the illustrated question about the correct use of spray/ inhaler drugs used by asthmatic children, $47.3 \%$ of the teachers chose the picture in "a" as the correct answer, 16.6\% in "b" and 12.3\% in "c". Twenty-three point four percent of the teachers answered as "I am not sure". Accordingly, only $12 \%$ know the correct use of the inhaler type medication used by the asthmatic child. While $64.2 \%$ of the teachers $(n=530)$ wanted a training seminar on childhood asthma, 35.8\% $(n=295)$ did not want to attend the training seminar. While $26 \%$ of the teachers had medical staff in their families, $74 \%$ did not have any medical staff in their families.

Regarding gender, there was a statistically significant difference between the scores of teachers' general knowledge about asthma, symptoms and triggering factors of childhood asthma, and the mean scores of female teachers' answers to childhood asthma were significantly higher than male teachers $(p=0.001)$. However, there was no statistically significant difference between female and male teachers in terms of emergency intervention, treatment evaluation and total asthma awareness scores.

There was no statistically significant difference between asthma knowledge, symptoms, triggering factors, emergency intervention, treatment and asthma awareness total scores according to the education level of the teachers.

There was no statistically significant difference between asthma knowledge, symptoms, treatment and total asthma awareness scores according to the expertise in teaching (professional experience). Knowledge scores of asthma triggering factors were found to be statistically significantly lower in teachers whose expertise in teaching was between 1-6 years compared to those between 7-12 years and over 12 years. It was found that there was no significant difference in the scores of the emergency intervention in the asthma crisis between teachers with an expertise in teaching between 1-6 years and between 7-12 years. The mean scores of emergency intervention in children with asthma crisis were found to be significantly lower in patients with an expertise in teaching for 12 years or more (Table 1).

Table 1. Evaluation of asthma awareness according to expertise in teaching (professional experience)

\begin{tabular}{|c|c|c|c|c|}
\hline & \multicolumn{3}{|c|}{ Expertise in teaching } & \multirow{2}{*}{$\begin{array}{l}p \\
\text { (One-way ANOVA) }\end{array}$} \\
\hline & $1-6$ years $(n=362)$ & $7-12$ years $(n=257)$ & $>12$ years $(n=207)$ & \\
\hline Asthma knowledge scores & $70.93 \pm 12.08$ & $72.65 \pm 12.23$ & $73.01 \pm 12.37$ & 0.088 \\
\hline Asthma symptom score & $68.47 \pm 14.55$ & $67.85 \pm 13.03$ & $67.66 \pm 14.90$ & 0.774 \\
\hline Triggering factors knowledge score & $53.99 \pm 14.75$ & $57.36 \pm 16.40$ & $56.62 \pm 14.68$ & 0.016 \\
\hline Emergency intervention knowledge score & $72.83 \pm 14.23$ & $72.98 \pm 15.62$ & $69.72 \pm 15.75$ & 0.033 \\
\hline Treatment knowledge score & $61.39 \pm 11.06$ & $60.96 \pm 9.55$ & $60.10 \pm 8.86$ & 0.340 \\
\hline Asthma awareness total score & $65.05 \pm 8.10$ & $65.21 \pm 7.93$ & $65.13 \pm 7.92$ & 0.970 \\
\hline
\end{tabular}


Teachers who had asthma in their kids, classes or relatives, or experienced an asthma attack in their classes, were considered to have experience with childhood asthma. The mean scores of the answers given by the experienced teachers to the questions about childhood asthma were found to be significantly higher than those without experience. Regarding asthma experience, there was a statistically significant difference between teachers in terms of asthma knowledge and triggering factors knowledge scores $(p=0.001$ and $p=0.024$; respectively). However, there was no statistically significant difference in terms of asthma symptoms, emergency intervention, treatment scores and total asthma awareness scores (Table 2).

No statistically significant difference was found between the teachers in terms of asthma knowledge, symptoms, triggering factors and emergency intervention scores according to school types. A statistically significant difference was found between asthma treatment and total asthma awareness scores according to school types ( $p=0.022$ and $p=0.001$, respectively). The total scores of treatment and asthma awareness of the teachers working in public schools regarding childhood asthma were significantly lower than the teachers working in private schools (Table 3).

There was no statistically significant difference between asthma knowledge, symptoms, triggering factors, treatment and asthma awareness scores of the teachers in terms of field of study. The mean scores of emergency intervention of classroom teachers were significantly lower than those of science and social sciences. There was no statistically significant difference between the other fields (Table 4).

There was no statistically significant difference between general knowledge, triggering factors, emergency intervention, treatment and asthma awareness total scores according to smoking status. A statistically significant difference was found between childhood asthma symptom scores according to smoking status $(p=0.021)$.

\section{Discussion}

Many studies conducted on the level of knowledge of childhood asthma showed that teachers' level of knowledge is limited (12-20). In the study

Table 2. Evaluation of asthma awareness according to asthma experience

\begin{tabular}{|l|l|l|}
\hline & Asthma experience & \multicolumn{1}{|c|}{} \\
\hline & Experienced (n=474) & Inexperienced (n=352) \\
\hline Asthma knowledge scores & $73.75 \pm 11.63$ & $69.66 \pm 12.61$ \\
\hline Asthma symptom score & $68.63 \pm 14.38$ & $67.25 \pm 13.92$ \\
\hline Triggering factors knowledge score & $56.75 \pm 15.69$ & $54.32 \pm 14.72$ \\
\hline Emergency intervention knowledge score & $71.66 \pm 14.24$ & $72.67 \pm 16.17$ \\
\hline Treatment knowledge score & $60.94 \pm 10.26$ & $60.97 \pm 9.87$ \\
\hline Asthma awareness total score & $\mathbf{0 . 1 6 5}$ \\
\hline
\end{tabular}

Table 3. Evaluation of asthma awareness according to school type

\begin{tabular}{|l|l|l|}
\hline & School type & $\mathbf{p}$ \\
\hline & Public (n=684) & Private (n=142) \\
\hline Asthma knowledge scores & $72.35 \pm 11.91$ & $70.34 \pm 13.53$ \\
\hline Asthma symptom score & $67.91 \pm 14.04$ & $68.69 \pm 14.96$ \\
\hline Triggering factors knowledge score & $55.84 \pm 15.31$ & $55.08 \pm 15.38$ \\
\hline Emergency intervention knowledge score & $71.84 \pm 15.18$ & $\mathbf{0 . 0 7 6}$ \\
\hline Treatment knowledge score & $60.58 \pm 10.27$ & $62.71 \pm 8.98$ \\
\hline Asthma awareness total score & $64.62 \pm 8.14$ & $\mathbf{0 . 5 8 9}$ \\
\hline
\end{tabular}

Table 4. Evaluation of asthma awareness according to field of study

\begin{tabular}{|c|c|c|c|c|c|}
\hline & \multicolumn{4}{|l|}{ Field of study } & \multirow{2}{*}{$\begin{array}{l}\text { p } \\
\text { (One-way } \\
\text { ANOVA) }\end{array}$} \\
\hline & Science $(n=106)$ & $\begin{array}{l}\text { Social sciences } \\
(n=105)\end{array}$ & $\begin{array}{l}\text { Class teacher } \\
(n=331)\end{array}$ & Other $(n=284)$ & \\
\hline Asthma knowledge scores & $71.09 \pm 13.04$ & $72.27 \pm 12.55$ & $72.92 \pm 11.30$ & $71.05 \pm 12.92$ & 0.243 \\
\hline Asthma symptom score & $61.17 \pm 16.10$ & $68.92 \pm 12.82$ & $67.05 \pm 14.27$ & $69.05 \pm 13.82$ & 0.280 \\
\hline Triggering factors knowledge score & $55.82 \pm 15.50$ & $55.54 \pm 16.61$ & $55.79 \pm 14.61$ & $55.59 \pm 15.59$ & 0.998 \\
\hline Emergency intervention knowledge score & $75.41 \pm 14.36$ & $75.59 \pm 16.50$ & $69.99 \pm 15.65$ & $71.85 \pm 13.78$ & 0.001 \\
\hline Treatment knowledge score & $62.23 \pm 10.69$ & $61.61 \pm 9.83$ & $60.40 \pm 9.85$ & $60.78 \pm 10.22$ & 0.361 \\
\hline Asthma awareness total score & $65.58 \pm 7.74$ & $65.99 \pm 7.87$ & $64.95 \pm 7.40$ & $65.07 \pm 7.82$ & 0.609 \\
\hline
\end{tabular}


conducted by Ones et al. (21), asthma awareness total score was found to be $74 \%$ and the answers given to the questions including the symptoms and general knowledge about asthma were found to be satisfactory. Among the symptoms of asthma, shortness of breath was known accurately at a rate of $71 \%$, wheezing at a rate of $50 \%$ and cough at a rate of $29 \%$. In our study, asthma awareness total score was found to be $65 \%$ and the answers given to the questions including the symptoms and general knowledge of childhood asthma were consistent with the other study, while the answers to the questions about the triggering factors had the lowest score with $55.7 \pm 15.3$. Among the symptoms of asthma, shortness of breath and wheezing were known accurately at a rate of $89.6 \%$ and cough at a rate of $81.4 \%$, and the rates were significantly higher than in the other study. This shows that, unlike the previous study, our teachers' level of knowledge about the most common and important symptoms of childhood asthma was satisfactory, but their asthma awareness total scores were lower.

In a study conducted with 792 elementary school teachers in 2006, asthma knowledge levels of women were found to be significantly better than men $(p=0.003)$. In our study, the mean scores of female teachers were also significantly higher than male teachers $(p=0.001)$. This difference was thought to be due to female teachers' interest in children's disease more than male teachers. Consistent with the literature data, there was no significant difference in asthma knowledge levels according to the educational status of the teachers.

In the study conducted with 199 teachers in 46 schools in Dublin City, teachers' level of knowledge about asthma symptoms and factors triggering attacks was found sufficient, however, knowledge about asthma treatment and emergency intervention was considered insufficient (22). In our study, teachers' knowledge of asthma treatment and emergency intervention was also evaluated as inadequate. Unlike the study in Dublin City, the answers to the questions about the factors triggering an asthma attack had the lowest mean score of 55.7 \pm 15.3 . This situation can be explained by the difference in social education and culture. These studies indicate that teachers should be educated on these issues and that schools need to develop an action plan especially in intervention in acute asthma attack.

In the studies evaluating the knowledge level of teachers about childhood asthma, it was found that teachers' age, gender and education levels did not affect their knowledge level about childhood asthma (23). Aydın Güçlü et al. (24) found that young age and female gender had a significant relationship with the number of correct answers in the questionnaire. In our study, it was found that the knowledge levels of the teachers who had master's degree were higher and there was a significant difference between the asthma knowledge levels of the teachers according to their education level. While there was no statistically significant relationship between professional experience and asthma knowledge level in our study, Canitez et al. (25) found that the knowledge level of teachers with 10 years or more professional experience on asthma was significantly higher.

In our study, similar to the studies conducted in the literature, having an experience of asthma caused a general knowledge level about asthma knowledge and triggering factors but did not affect having sufficient knowledge about treatment and emergency intervention requiring more specific information.

In a study conducted with 76 teachers in 11 primary schools, including eight public and three private schools, in Southampton, teachers were asked about the symptoms of childhood asthma, triggering factors, treatment and emergency intervention, and teachers' level of knowledge about asthma was found to be very low. It was found that there was no significant difference in asthma knowledge levels of teachers working in public and private schools. Eighty-six percent of the teachers requested to be informed about asthma (26). In our study, it was found that asthma knowledge levels of teachers working in public schools were significantly lower. In private schools, it was found out that the parents met with the teachers more often and shared the information about their children frequently and that this situation affects the development of teachers' knowledge about the diseases of the children. In addition, teachers are given frequent trainings on child health issues. Therefore, it is thought that teachers working in private schools have better knowledge about childhood asthma.

In childhood asthma, it is very important to regulate appropriate treatment in order to control the disease and to prevent irreversible damage to the respiratory tract and patient adherence to treatment is also very important. In patients with difficult pediatric asthma where control cannot be achieved with effective treatment, it is necessary to question the differential diagnosis and whether the treatment is applied correctly and regularly (27). In a study conducted by De Boeck et al. (28) in 51 patients with the diagnosis of difficult pediatric asthma, it was shown that all of them had symptom control, that four of them had no asthma and that only five of them had a slightly worse symptom control. In school-aged asthmatic children, the role of teachers as well as family and patient is important in terms of treatment compliance. It may be necessary to check whether the children who spend most of their time at school receive their treatment in a timely and correct manner or not, and emergency intervention methods, asthma symptoms and attack triggering factors should be known by the teacher and some applications should be performed. Therefore, the correct use of inhalertype medications used in the treatment of asthma should be known by teachers. Similar to the studies conducted in Europe and the USA, in our study, only $12 \%$ of the teachers correctly answered the illustrated question asking about the use of inhaler medications used in asthma treatment, while $23 \%$ stated that they were not sure $(29,30)$. It is very important in terms of demonstrating the necessity to provide training on the use of inhaler drugs.

\section{Study Limitations}

If the teachers were informed with seminars or trainings and evaluated before and after the training, we would have the opportunity to have information about the necessity and effectiveness of the training.

\section{Conclusion}

In order to control asthma and prevent the development of attacks, it is very important to know the triggering factors and to create suitable living spaces in the school. The continuation of prophylactic treatment without interruption in school time will be ensured by raising the 
awareness of teachers. Action plans for asthma attacks (asthma friendly school, etc.) should be prepared in each school. Information can be provided effectively by health personnel by seminars and brochures. Collaboration between student, family, teacher and doctor is essential for treatment success and decreasing the frequency of attacks in asthma. In order for teachers to take a more active role in this cooperation, their knowledge levels should be increased by providing trainings on childhood asthma. Our research will contribute to the preparation of guidelines that include training programs for teachers as well as the development of a country-specific strategy in our national asthma control program.

Ethics Committee Approval: Ethics committee approval was obtained for the study (Istanbul University Training and Research Hospital Ethics Committee (decision no: 16/J, date: 25/10/2011).

Informed Consent: Informed verbal and written informed consent was obtained from the teachers.

Peer-review: Externally peer-reviewed.

Author Contributions: Concept - Ö.Ö., M.S.; Design - Ö.Ö., M.S.; Supervision - Ö.Ö., M.S.; Resources - Ö.Ö., M.S.; Materials - Ö.Ö., M.S.; Data Collection and/or Processing - Ö.Ö., M.S.; Analysis and/or Interpretation Ö.Ö., M.S.; Literature Search - Ö.Ö., M.S.; Writing Manuscript - Ö.Ö., M.S.; Critical Review - Ö.Ö., M.S.

Conflict of Interest: No conflict of interest was declared by the authors.

Financial Disclosure: The authors declared that this study received no financial support

\section{References}

1. Baterman ED, Hurd SS, Barnes PJ, Bousquet J, Drazen JM, Fitzgerald M. et al. Global strategy for asthma management and prevention. Eur Respir J 2008; 31: $143-78$.

2. Pearce N, Weiland S, Keil U, Langridge P, Anderson HR, Strachan D, et al. Selfreported prevalence of asthma symptoms in children in Australia, England, Germany and New Zealand: an international comparison using the ISAAC protocol. Eur Respir J 1993; 6: 1455-61.

3. No authors listed. Worldwide variation in prevalence of symptoms of asthma, allergic rhinoconjunctivitis, and atopic eczema: ISAAC. The International Study of Asthma and Allergies in Childhood (ISAAC) Steering Committee. Lancet 1998; 351: 1225-32.

4. Ones U, Akcay A, Tamay Z, Guler N, Zencir M. Rising trend of asthma prevalence among Turkish school children (ISAAC phases I and III). Allergy 2006; 61: 144853.

5. Kurt E, Metintas S, Basyigit I, Bulut I, Coskun E, Dabak S, et al. Prevalence and risk factors of allergies in Turkey: Results of a multicentric cross-sectional study in children. Pediatr Allergy Immunol 2007; 18: 566-74.

6. Uyan AP, Gözükara A, Yesildal N. Prevalence of asthma and allergic disorders among children in Düzce, Turkey: ISAAC Phase One. The Int J Epidemiol 2003: 1.

7. Çakır M, Çetinkaya F. Samsun'da ilköğretim okulu çocuklarında astım ve diğer allerjik hastalıkların sıklığı. Astım Allerji İmmünoloji 2004; 2: 139-42.

8. Hill RA, Standen PJ, Tattersfield AE. Asthma, wheezing, and school absence in primary schools. Arch Dis Child 1989; 64: 246-51.
9. Bener A, Abdulrazzaq YM, Debuse P, Abdin AH. Asthma and wheezing as the cause of school absence. J Asthma 1994; 31: 93-8.

10. Freudenberg N, Feldman $\mathrm{CH}$, Clark NM, Millman EJ, Valle I, Wasilewski Y. The impact of bronchial asthma on school attendance and performance. J Sch Health 1980; 50: 522-6.

11. Mitchell RD, Dawson B. Educational and social characteristics of children with asthma. Arch Dis Child 1973; 48: 467-71.

12. Clark NM. Community-based approaches to controlling childhood asthma. Ann Rev Public Health 2012; 33: 193-208.

13. Anderson S. A national policy on asthma management for schools. J Paediatr Child Health 1994; 30: 555.

14. Sawyer SM. Asthma friendly schools: the importance of school policy for children with asthma. J Paediatr Child Health 2006; 42: 483-5.

15. Fillmore EJ, Jones N, Blankson JM. Achieving treatment goals for schoolchildren with asthma. Arch Dis Child 1997; 77: 420-2.

16. Boyle JS, Baker RR, Kemp VH. School-based asthma: a study in an African American elementary school. J Transcult Nurs 2004; 15: 195-206.

17. Hill R, Williams J, Britton J, Tattersfield A. Can morbidity associated with untreated asthma in primary school children be reduced?: a controlled intervention study. BMJ 1991; 303: 1169-74.

18. Hill RA, Britton JR, Tattersfield AE. Management of asthma in schools. Arch Dis Child 1987; 62: 414-5.

19. Henry RL, Lough S, Mellis C; Australasian Paediatric Respiratory Group. National policy on asthma management for schools. J Paediatr Child Health 2006; 42: 491-5.

20. Levy M, Heffner B, Stewart T, Beeman G. The efficacy of asthma case management in an urban school district in reducing school absences and hospitalizations for asthma. J Sch Health 2006; 76: 320-4.

21. Ones U, Akcay A, Tamay Z, Guler N, Dogru M. Asthma knowledge level of primary school teachers in Istanbul, Turkey. Asian Pac J Allergy Immunol 2006; 24: 9-15.

22. Hussey J, Cahill A, Henry D, King AM, Gormley J. National school teachers' knowledge of asthma and its management. Ir J Med Sci 1999; 168: 174-9.

23. Juhn YJ, Sauver JS, Shapiro ED, McCarthy PL. Child care program directors' level of knowledge about asthma and factors associated with knowledge. Clin Pediatr (Phila) 2002; 41: 111-6.

24. Aydın Güçlü Ö, Karadağ M, Macunluoğlu AC, Demirdöğen Çetinoğlu E, Ediger D. Bursa ilindeki öğretmenlerin astım farkındalığının değerlendirilmesi. Tuberk Toraks 2018; 66: 150-5.

25. Canitez Y, Çekiç S, Celik U, Kocak A, Sapan N. Health-care conditions in elementary schools and teachers' knowledge of childhood asthma. Paediatr Int Child Health 2016; 36: 64-71.

26. Brookes J, Jones K. Schoolteachers' perceptions and knowledge of asthma in primary schoolchildren. Br J Gen Pract 1992; 42: 504-7.

27. Yuksel H. Pediatrik zor astım ve tedavisi. Türk Ped Arș 2010; 45: 80-5.

28. De Boeck K, Moens M, Van Der Aa N, Meersman A, Schuddinck L, Proesmans M. Difficult asthma: can symptoms be controlled in a structured environment? Pediatr Pulmonol 2009; 44: 743-8.

29. Stohlhofer B, Lahrmann H, Frank W, Zwick H. Report on the current knowledge of Vienna primary school teachers about bronchial asthma in children. Pneumologie 1998; 52: 406-11.

30. Bruzzese JM, Unikel LH, Evans D, Bornstein L, Surrence K, Mellins RB. Asthma knowledge and asthma management behavior in urban elementary school teachers. J Asthma 2010; 47: 185-91. 